\title{
Future-making in Burkina Faso: ordering and materializing temporal relations in the Bagré Growth Pole Project
}

\author{
Janine Hauer $^{1,2}$ \\ ${ }^{1}$ IRI THESys, Humboldt-Universität zu Berlin, Berlin, Germany \\ ${ }^{2}$ ZIRS, Martin-Luther-Universität Halle-Wittenberg, Halle, Germany \\ Correspondence: Janine Hauer (janine.hauer@hu-berlin.de)
}

Received: 18 May 2020 - Revised: 4 March 2021 - Accepted: 8 March 2021 - Published: 4 May 2021

\begin{abstract}
Visions for the future drive current practices and shape daily lives. Recently, the future has also become a ubiquitous theme in the social sciences. Starting from the observation that the future serves as an explanation and legitimization for the doings and sayings of different groups of actors involved in the Bagré Growth Pole Project in Burkina Faso, this paper offers an analysis of two instantiations of future-making. Based on 9 months of ethnographic fieldwork in Burkina Faso, I examine how the future is addressed and made by ordering and materializing temporal relations. In the first part, I focus on how the past-present-future triad is constantly cut, the past blanked and the future prioritized. I argue that this imperative of the future serves to silence contestations and conflicts from which possibly alternative futures could be derived. In the second part, I turn to the material dimension of future-making through infrastructure construction and maintenance. Infrastructuring in Bagré permanently alters landscapes and creates "as-if" spaces, thereby producing path dependencies that will channel future possibilities of living in the area. Shedding light on how specific futures are (un)made in practice provides a lens which may inform discussions about alternative and eventually more just futures.
\end{abstract}

\section{Introduction}

I first met the director of the Maison de l'Entreprise du Burkina Faso (MEBF) office in Bagré in early June 2017 in the capital Ouagadougou. I was tracing a network of rice selling points set up by the MEBF together with an NGO to propagate the rice of Bagré among the urban population of Burkina Faso's capital that preferred imported rice from India, Thailand and China among others. Asian rice, I was told, was cheaper and would "puff up" when being cooked, thereby filling more hungry bellies. The government of Burkina Faso together with international partners and NGOs had thus made it a priority to increase national rice production to reduce imports since the global food price crisis in 20072008. I had come to Burkina Faso to trace how Africa's rice promise (Wopereis et al., 2013) was being realized in practice and what the implications for the land and livelihoods of local populations were. Hearing about my project, the director of Bagré's MEBF office immediately invited me to come to Bagré "le grenier du Faso", Burkina's granary, as he put it, because this is "where you need to go to see what the rice future looks like" (fieldnote - FN, 4 July 2017). Two weeks later, there I was. Together with the director and four other staff members I was sitting at a table in the MEBF's satellite office in Bagré. Bagré was a perfect case study and a flagship, they told me. The brand name "riz de Bagré" was wellknown all over the country. Furthermore, Bagré had "une vision" that different actors working directly or indirectly in the rice sector were committed to; it would provide 30000 ha of irrigable land where family farms would mainly grow rice but also maize, onions and other vegetables. They would work hand in hand with larger investors who would take care of processing and disseminating the latest research advances regarding varieties and cultivation techniques to "feed the country". Livestock production and ecotourism would be supplementing activities. Altogether the mixture would create jobs for women and the youth. Bagré was pictured as an exemplary growth pole and a model for the future of 
Burkina's agriculture (FN, 20 July 2017). During the following weeks I met rice farmers, processors and vendors, plain managers and field agents, and bank employees and rice researchers who reported on precarious living conditions, broken infrastructure, lack of coordination and engagement, delayed payments, and the challenges of applying local solutions to globalized problematizations. I also learned that the initial estimations of around 30000 ha of irrigable lands had been re-estimated to a total of 16700 ha, with only 3380 ha being irrigated by the time of my research. Yet, these problems were framed as temporary, rooted in individuals' incapacities or deficits in management. The prosperous future prospect however was defended and Bagré's vision upheld: Bagré had the potential to be the cart horse for the country's economy, with 30000 ha of fertile irrigable farm land, where 30000 jobs would be created and where smallholders and large investors would work hand in hand to feed the country.

In this paper I look at two recurring instantiations of future-making in Bagré and place them within current discussions of what can be termed anthropologies and geographies of the future. Starting from the observation that the future repeatedly serves as an explanation and legitimization for the doings and sayings of different groups of actors involved in the Bagré Growth Pole Project in Burkina Faso, I analyze how its presence shapes the everyday practices as well as material realities of life in Bagré and the consequences of such ordering and infrastructuring of temporal relations.

A plethora of attempts to "bring the future back in" (Appadurai, 2004: 60) are currently observed across the social sciences. The "future matters" (Adam and Groves, 2007), "remains" (Akerman et al., 2017), condenses into "sociotechnical imaginaries" (Jasanoff and Kim, 2009) and forms "dreamscapes of modernity" (Jasanoff and Kim, 2015). As such, it relies on the "the capacity to aspire" (Appadurai, 2004). Indeed, the future is a "cultural fact" (Appadurai, 2013). Different visions for the future orient us differently in the present (Nielsen, 2011, 2014; Bryant and Knight, 2019). These orientations make the future empirically graspable. Studies of the future and how the future is envisioned, enacted and brought into being have focused on, for example, anticipation (Anderson, 2010; Cross, 2014; Greiner, 2016; Geenen, 2018), expectation (Ferguson, 1999; Beckert, 2013, 2016; Kornienko, 2014; Ringel, 2018) and hope (Braun, 2005; Anderson and Fenton, 2008; Jansen, 2014; Hauer et al., 2018). While this paper is inspired by these discussions on temporality and futurity, its point of departure is more empirical and arose directly from fieldwork situations such as the one described above. While a range of current problems and conflicts related to the Bagré Growth Pole Project were repeatedly brought up, they were hardly ever practically addressed. Rather, they seemed to be set aside in favor of depicting and referencing a future "yet to come". Although some of my interlocutors would occasionally describe Bagré as a "powder keg" that had "explosive potential", I never came to witness open contestations or resistance against the everyday decisions and process of the project. Rather such utterances were quickly silenced by pointing to Bagré's vision for the future.

The remainder of this paper is structured as follows: I will start by describing the details of the fieldwork and empirical material this paper is based on, including how it was analyzed. Afterwards, I will briefly look into the current discussions that address the future in anthropology and human geography that inspired the analysis that follows. Subsequently, I will sketch the emergence of the Bagré Growth Pole Project as a "tool of future-making" (Müller-Mahn, 2019: 3) by opening up new lands for new crops and new business opportunities, before delving more deeply into two modes of future-making in Bagré: in the first part of the analysis, I show how the past-present-future triad is constantly cut, the past blanked and the future prioritized. I argue that this imperative of the future serves to silence contestations and conflicts from which possibly alternative futures could be derived. In the second part, I turn to the material dimension of future-making through infrastructure construction and maintenance. Infrastructuring in Bagré permanently alters landscapes and creates "as-if" spaces, thereby producing path dependencies that will channel future possibilities of living in the area. In the concluding section I argue that shedding light on how specific futures are (un)made in practice provides a lens which may inform discussions about alternative and eventually more just futures.

\section{Methods}

In this paper I draw on 9 months of ethnographic fieldwork in Bagré and Ouagadougou in Burkina Faso from May to November 2017 and May to August 2018. The overall research aimed at providing an understanding of the socioecological changes and dynamics that the implementation of a large-scale development project - the Bagré Growth Pole Project - brought to the region of Bagré. A particular focus was given to rice production. The fieldwork was accomplished in Ouagadougou and Bagré, with only occasional visits to other parts of the country. Fieldwork in Ouagadougou concentrated on the project management level and its broader organizational and political environment as well as on the marketing and consumption side of the rice sector. The capital is the location of ministries, research institutes, project funders' offices and professional organizations as well as a dense network of rice sellers. In Ouagadougou, I conducted 12 semi-structured expert interviews (Longhurst, 2003; Bogner et al., 2009; Dunn, 2010) that helped me to gain an understanding of the organization of the rice sector and the Bagré Growth Pole Project in particular. Moreover, I had 35 conversations with rice sellers that focused on their specific supply networks. Fieldwork in Bagré in turn was more participatory. I lived in Bagré Chantier, a district just below the Bagré dam that had co-developed with the dam 
and that hosted satellite offices of the project's managing institutions, banks and stakeholder offices, a military base, and housing for construction workers. It also constituted the commercial center of the region with a market, shops and processing facilities for different agricultural products, e.g., rice. Living close to "where the action is" (Schatzki, 2011) allowed for a more practice-oriented mode of fieldwork: I joined farmers in the fields throughout all stages of rice farming and participated in training and meetings of and among farmers, processors and zone managers. I could also follow the progress of construction and maintenance work and talk to researchers and actual and potential donors that visited the zone. While I also conducted 11 expert interviews and 35 semi-structured interviews with rice farmers specifically on their support networks and selling strategies, most of the data I gathered in Bagré took the form of field notes that included daily observations and conversations on the rice fields; at the kiosk; or in the streets between the market, the bank or the offices of Bagrépôle and the Maison de l'Entreprise - the two project-implementing agencies of the Bagré Growth Pole Project. Moreover, I joined a couple of encounters between farmers, processors and project managers, such as a series of consultant-led meetings to reform the rice processor cooperative and meetings with the farmer union to discuss potential projects, the World Bank and other donors' field visits. Instead of focusing on one particular group of actors, this mobile mode of fieldwork allowed me to tackle the manifold relations that are constantly made and unmade by the Bagré Growth Pole Project and to grasp the sometimes contradictory positions within specific groups of actors vis-à-vis other groups.

When possible, formal interviews were digitally recorded; more informal conversations were roughly minuted and later written down in field notes. Both interviews and field notes were coded in MAXQDA according to recurring themes in the field as well as academic discussions. Whereas most interviews on the managing side were conducted in French (and translated to English) by the author, many conversations in Bagré were held in Mooré or Bissa with the help of a research assistant, who also translated them into French. Working with an assistant was particularly instructive, because the joint translation work repeatedly led to long conversations about the broader context, history and situatedness of what was said and done (Gupta, 2014; Middleton and Cons, 2014).

Finally, the analysis of interviews and first-hand observations was supplemented by texts and documents that circulated in the field, such as laws and regulations, studies and reports on the project status, and figures and numbers from the project managers. Most of these documents were not publicly accessible but provided by the project-implementing agencies that I visited and talked to regularly during my field stays.

\section{Discussing the future in anthropology and geography}

While the future has long been an implicit concern for both human geographers and anthropologists, it has rarely been made an explicit empirical or analytical focus (Appadurai, 2013; Anderson, 2010). However, recently, in the light of economic, financial and ecological crises and increasingly precarious living conditions, the uncertainty of the future itself and the uneven distribution of capacities to aspire (Appadurai, 2004) have led geographers and anthropologists to address the future of particular human-environment relations more thoroughly. Moreover, both disciplines share the "struggle" of finding their roles in a world that seems to be entirely mapped. ${ }^{1}$ One way to read this renewed interest is to highlight the disciplines' common interest in the future as a response to the "belatedness" of fieldwork (Marcus, 2016: 144) and the "desire to be relevant" (Marcus, 2016: 149). Writing anthropologies and geographies of the future can thus be regarded as an attempt to rethink "the future of geography" (Thrift, 2002) and anthropology themselves, that is to claim their relevance for actively shaping the future in and of the fields of research.

Discussions on the future within anthropology and geography alike bring together insights from a range of subfields, such as studies of development and planning practice as well as a growing body of research on infrastructure and megaprojects. These works cultivate sensibilities, which help us to empirically and analytically grasp an understanding of the future that is "inaccessible to factual empirical study" (Adam, 2008: 5).

Development, as has been noted by geographers and anthropologists alike, "is by design a temporal and forwardlooking project" (Wiegink, 2018: 245). While development workers and institutions tend to focus on the delivery of positive change (improvement) and transformation (radical shift of the current state), empirical studies have pointed to the (dis)continuities of development as a long-term process (Lewis, 2009). By looking at the broken promises of development in terms of both livelihoods (Ferguson, 1999) and landscapes (Stoler, 2013), works from development geography and anthropology contribute to studies of the future by pointing to the contested nature of future visions. The future in many cases is not designed by those who are supposed to inhabit it and asked or forced to break with their pasts. In

\footnotetext{
${ }^{1}$ To what extent the interest in a fuzzy concept such as the future points towards a lack of general theoretical or political orientation in the social sciences would be an interesting question to explore Attempts to reformulate anthropology's agenda such as the work of Paul Rabinow et al. (2008), Designs for an Anthropology of the Contemporary, or reflections on the current state of geography as brought forth in a debate by Carolin Schurr and Peter Weichhart at the German Congress for Geography in Kiel in 2019 point in that direction. I thank one of the anonymous reviewers of this paper for pointing this out
} 
contrary to the notion of development, which is associated with linearity and western notions of modernization, placing these works within the broader realm of the future opens up spaces for different visions of and paths for what that future might look like in concrete terms.

Similarly, studies on urban design and planning direct our attention to the material forms and their dis- or enabling potential for future possibilities. To plan means to imagine the future and to control the passage towards this future (Abram and Weszkalnys, 2013; Elliott, 2016). The notorious argument between Robert Moses and Jane Jacobs as to whether existing structures within cities have to be destroyed to realize truly innovative urban forms or whether city planning has to preserve and incorporate existing urban features (Sennett, 2018 ) is a prominent example of this.

Closely connected to questions of both power and materiality, infrastructure, as a field of study (Hull, 2012; Meehan, 2014; von Schnitzler, 2016; Barnes, 2017; Ballestero, 2019), as well as a conceptual lens (Star, 1999; Niewöhner, 2015; Howe et al., 2015), has been connected to discussions about the future. Infrastructure comprises "force-full" objects (Meehan, 2014), simultaneously "promising forms" (Larkin, 2013, 2018) through which the future becomes legible (Trovalla and Trovalla, 2015) and tangible (Hauer et al., 2018) and often being "unbuilt and unfinished" (Carse and Kneas, 2019) representatives "of an unrealized future" (Yarrow, 2017).

To summarize, current works under the header of anthropology and geography of the future are by no means new, nor do they constitute a coherent emerging field of research or theorization. Rather they bring together a range of more classical subfields in which the centrality of future orientations come together empirically and analytically.

Strikingly, ideas of development and how it can be planned and infrastructured converge in megaprojects such as growth poles and development corridors. These large infrastructures have recently become prominent research fields for human geographers and anthropologists (e.g., Mosley and Watson, 2016; Enns, 2018, 2019; Dannenberg et al., 2018; Stein and Kalina, 2019; Hauer and Nielsen, 2020; Chome et al., 2020). Conceptually grounded in post-World War II (re)industrialization of the 1950s (Wang and Li, 2017), growth poles and development corridors have re-emerged as spatial development strategies (Schindler et al., 2019: 1). In the aftermath of the global food, fuel and finance crisis in 2007-2008, they promise to "rais[e] competitiveness and deepen regional integration" (Speakman and Koivisto, 2013) across Africa and the Global South more broadly. Growth poles and corridors alike share an emphasis on infrastructure development, the promotion of public-private partnerships and their concentration within specific geographical boundaries (Speakman and Koivisto, 2013; Picard et al., 2017). Taken together, these components are supposed to unleash the transformational potential that animates much of the cur- rent discourse on African futures (e.g., Goldstone and Obarrio, 2016a).

The study of these megaprojects features prominently among current discussions about the future. Empirical inquiries of what happens when these "development blueprints" (Mosley and Watson, 2016: 453; Müller-Mahn, 2019: 1) "hit the ground" (Chome et al., 2020) provide insights into how specific ideas of the future are enacted in the here and now. While all of these works are placed within and contextualized by the broader future orientation that drives these projects, they analytically focus on questions as diverse as the role of these projects for state- and nation-building (Mosley and Watson, 2016), the role of divergent expertise in contesting land deals related to such projects (Enns, 2019), and the political economy of development corridors (Chome et al., 2020), as well as spatial and social (dis)integration (Dannenberg et al., 2018). Pointing to the contested and paradoxical nature of these projects and the "contrast between imaginary and situated reality" (Stein and Kalina, 2019: 83), such research has recently triggered more systematic reflections on the future itself as both an analytical vantage point for scholarly inquiry (Ouma et al., 2019; see also Goldstone and Obarrio, 2016b; Bryant and Knight, 2019) and a horizon our research actively intervenes with (Appadurai, 2013: 285-300).

This paper aims to contribute to these writings by departing from the future as an empirical concern repeatedly raised and addressed by the people working for and being affected by the Bagré Growth Pole Project. It does so by carving out two instantiations of how the future is made - verbally and materially - and analyzing the effects of these specific modes of future-making.

\section{African agrarian futures - new lands for new crops and opportunities for investment in Bagré}

Burkina Faso is situated in the center of West Africa. As a landlocked country with no significant natural resource deposits, the former French colony Upper Volta was mainly conceived of as a labor reserve for the more viable southern colonies (Harsch, 2017). After its independence in 1960 the country struggled to find its place in the world economy. Except for the export of cotton and more recently gold (OEC $2018^{2}$ ), Burkina Faso's overly rural population mainly depends on subsistence agriculture for making a living. Around $80 \%$ of the population generate their primary income from agriculture, which accounts for roughly one-third of the national gross domestic product (FAO, 2014). Due to rapid population growth, the demand for staple foods is constantly increasing. However, as a result of massive urbanization (Prat, 1996; Hilgers, 2008) and related changing diets, the demand for staple foods is shifting from traditional crops such as mil-

\footnotetext{
${ }^{2}$ https://oec.world/en/profile/country/bfa, last access: 30 November 2020.
} 
let and sorghum to, most prominently, rice. Rice is currently the fourth most important staple crop in the country, after sorghum, millet and maize (GRiSP, 2013: 205), but its consumption is rapidly outgrowing other staples.

Rice started to enter the country's foodscape (MacKendrick, 2014) through international food aid supplies and has since spread rapidly due to increasing imports from the 1980s onwards (Bonnecase, 2016: 15). To counterbalance an increase in imports, national rice production was started, supported and continuously expanded by government investments and foreign financial and technical aid. Constantly challenged by unstable and unfavorable climate conditions of the semi-arid climate including very variable rainfall during the rainy season from June to October (Faure, 1996: 11), irrigation was and still is generally considered the only solution to building resilient and productive rice production in Burkina Faso (Dialla, 2002: 63; see also Ouedraogo and Sedogo, 2014; Venot et al., 2017). However, the use of surface water from the rivers for irrigation was severely hindered by the high prevalence of onchocerciasis, river blindness disease, which was widely spread across the river valleys in West Africa until international aid organizations launched the Onchocerciasis Control Programme (OCP) in 1974 and successfully eradicated the disease (Yaméogo, 2006: 62-63). The river valleys, such as the Bagré region in the southeast of Burkina Faso, thereby gained political attention as they now provided fertile soils and water resources (Yaméogo, 2015). The government created an authority for the development of the Volta valleys (AVV - Autorité des aménagements des vallées des Volta) and placed it in charge of the valorization of the natural resources of the Volta valleys, including the area that would later become the venue of the Bagré Growth Pole Project.

After conducting several technical, economic and financial feasibility studies in the 1970 s, the interventions in the Bagré area started in 1980 with more detailed execution studies (Bagrépôle, no date available). Moreover, from 19801983 a pilot project called Petit Bagré was financed and implemented by the Taiwanese development agency, in which 80 ha of irrigable parcels was developed for rice production (Faure, 1996: 265). The first rice farmers to cultivate that land were mainly recruited from among the autochthon Bissa population from the surrounding villages (Yaméogo, 2006: 85). In addition to an average of 0.8 ha of irrigable rice parcels, these farmers were assigned around 3 ha of garden and bushland for vegetable and maize cultivation (Yaméogo, 2006: $85)$.

The opening up of the river valleys for agricultural production was pushed further by the coming to power of Thomas Sankara in 1983. His 1984 national land reform "Réforme agraire et foncière" (RAF) nationalized all land and natural resources and officially abolished traditional authority over land (Faure, 1996). Migrants were encouraged to settle along the river valleys as they officially no longer relied on authorization by the local Bissa population, who are the custom- ary landowners and traditional administrators of land across the area. This resulted in contestation and the de facto coexistence of different and even hybrid tenure systems (De Zeeuw, 1997; Dialla, 2002; Yaméogo, 2006; Mathieu et al., 2003). Revisions of the RAF in 1991 and 1996 gradually reintroduced private property and granted a legal status to territorial collectives, considering traditional modes of land management that in effect never ceased to exist. However, state authority still has to grant ultimate land rights by certification. Also, private or collective rights can be withdrawn for public interest. This happened in Bagré in 1998 when the area around the Bagré dam was declared a "Zone d'Utilité Publique" (ZUP), which enabled the government to withdraw the land from the local population without further negotiation or compensation (World Bank, 2010a).

Following the Petit Bagré project, the Bagré dam was constructed and finally inaugurated in 1995. Two main canals and a system of secondary and tertiary canals irrigate the river valley on the left and right bank of the Nakanbé. Between 1995 and 2009 a total of 3380 ha of irrigable farmland was created in several project phases and was funded from different sources such as the European Union and the International Cooperation and Development Fund of Taiwan among others (Bazin, 2017; Korbéogo, 2020: 76). The local Bissa population showed little interest in rice farming; thus, Mossi migrants from other regions of the country were recruited to the Bagré region to become rice farmers.

However, the allocation of the expensively converted rice plains was soon deemed too costly and therefore inefficient by the funding and managing bodies. Whereas the first irrigated schemes -1200 ha on the right bank and 600 ha on the left bank - were exclusively allocated to smallholders, who received around 1 ha each, the first extension of 1500 ha was originally destined to agro-investors, who would receive bigger plots and in turn contribute to the construction and maintenance of the irrigation infrastructure to reduce construction costs (World Bank, 2011). However, emerging land conflicts and protests led the parastatal MOB (Maîtrise d'Ouvrage de Bagré) that was in charge of the land management to change this plan and to yield to the pressure of the growing local population. Ultimately, 1200 of 1500 ha was attributed to smallholders and only 300 ha to agro-investors (Kaboré and Sédogo, 2014; Bazin, 2017).

To pursue the construction of the irrigation system and hit the initial target of 30000 ha of irrigable land figured in the early feasibility studies, the World Bank-funded Bagré Growth Pole Project was launched in 2011. Its scope was much broader than that of the previous projects that mainly pushed smallholder rice production. The previous experiences with uprisings against the allocation of land to largescale investors were taken up and a twofold approach pursued from the beginning. Whereas gravity-based irrigation was installed to be allocated to smallholders only, higher lands that could only be irrigated by pumping were reserved for agroinvestors. The latter would supposedly be able to contribute 
to infrastructure development such as extending the canal systems or installing pumps to get water from the primary canal to the fields. The newly constructed fields were also no longer destined for rice production only; rather farmers were encouraged to diversify their cropping cycles (interview with Bagrépôle, 4 July 2018). Of the current extension of 4394 ha, $2072 \mathrm{ha}$ is dedicated to smallholders while 2322 ha is allocated to commercial agro-investors.

Along with the extension of the canal system and irrigation scheme, new institutions and service providers such as gas stations, hotels and banks have opened in Bagré. Furthermore, Bagrépôle (the successor of the MOB) and the Maison de l'Entreprise du Burkina Faso (MEBF), the two main implementing institutions of the Bagré Growth Pole Project, hold satellite offices in Bagré. Bagrépôle acts as the zone authority and leads the construction of the irrigation scheme; infrastructure development; and management of the agricultural activities in the zone, including land and water management and crop calendar coordination. The Maison de l'Entreprise in turn aims at strengthening the private sector's engagement in order to promote economic development. The wider project area, 500000 ha of land, has the special status called a Zone d'Utilité Publique (ZUP) that allows for state interventions with few restrictions (a point that I will take up in the following section).

Over time, Bagré has become a flagship initiative of the national government that attracts a broad range of interand transnational donors and partners and receives considerable public attention. According to the authorities the Bagré Growth Pole is a vanguard for further growth pole projects across the country (Coulibaly, 2019). When the managing director of Bagrépôle gave an interview to a journalist in 2019, the latter recalled the visionary beginnings of the project asking "wasn't the dream too big?" (Bassole, 2019, all translations by Janine Hauer). In his response, the managing director oscillates between what is and what will be: "We obviously experience a time lag, which might prompt public concerns.... But the dream is still alive and realizable" (Bassole, 10 December 2019). It is in this interstice between the current state as it is practiced and experienced on an everyday basis and a future state as it is envisioned that the following analysis is placed. Tracing the practices and infrastructures that emerge in between the everyday life in Bagré and its orientation towards the future state of the Growth Pole, I subsequently account for future-making in Bagré.

\section{Modes of future-making in practice in Bagré}

\subsection{Prioritizing the future, dismissing the past}

In 2010 the government of Burkina Faso, most notably agents from the Ministry of Finance and Budget, prepared a 12-page-long concept document for the World Bank providing the rationales for the bank's involvement in a project titled the Bagré Growth Pole Project, including its objectives, description and project components (World Bank, 2010a). Following this initiative, the World Bank put financial support at the government's disposal in a full project proposal (World Bank, 2010b). The final proposal, which details the plans to establish the country's first growth pole in the Bagré area, was submitted and positively evaluated in May 2011 (World Bank, 2011). According to this document, the project's overall objective "is to contribute to increased economic activity in the Project Area, resulting in an increase in private investment, employment generation and agricultural production" (World Bank, 2011: ii). To achieve this goal three major project components are listed:

1. the improvement of institutional capacity for better zone management and investment climate in the Project Area by strengthening the project managing institution, the MOB (Maitrise d'Ouvrage de Bagré), which became Bagrépôle in 2012;

2. the development of critical infrastructure, most notably the extension of irrigation infrastructure for agricultural development; and

3. the development of critical services and direct support to smallholders and Small and Medium Enterprises by providing technical support and capacity building (World Bank, 2011: iii).

As an overall picture the 156 pages of the final project proposal sketch the government's vision for one of the backbones of the country's economy, namely agriculture: "core public and private irrigation-based investments that would be promoted by the Project", a diversified agriculture including a focus on inputs and processing and gaining access to markets, as well as a "sustainable development of all resources $\ldots$ are expected to yield significant changes for the population" (World Bank, 2011: 105). Thereby, it reflects and condenses a range of existing strategies for the country's agricultural sector (Burkina Faso, 2011) including the National Strategy for the Development of the Rice Sector (MAAH, 2011) among others.

In addition to the future outlook, the document also reveals a specific view of the relationship between the future and the past:

"Burkina is at a crossroads. The country can choose to tackle the distortions that have reduced incentives for investment and productive activity, create the necessary conditions for a shift from low-input/low output subsistence farming to diversified and high income-enhancing agriculture, and move toward sustainable and diversified growth. The country could build on islands of success and promising cluster initiatives and enclaves that can then pull along the rest of the economy (successfully achieved in China and India, Malaysia and being tested in Zambia, Mozambique etc.) or it can 
ignore the reform imperatives and pay the price of having a highly distorted, rentier economy based on cotton." (World Bank, 2011: 33)

In this text passage the pathway to the future is framed as being dependent first and foremost on active choice. Moreover, the future appears as something new and better that breaks from the past. The idea of consciously breaking with the past in order to participate in a future that is shared with others, e.g., "China and India", orients many quotidian situations in Bagré and is not only promoted by project managers but was - to my surprise - adopted by local farmers and project-affected people, as I will show in the following. The role of the project in this respect is the provision of the tools that are needed to successfully enter the future, but they have to be employed and distributed in the right way.

In the conversations I had with representatives and employees of Bagrépôle and external consultants who supported the implementation of the various project components, the need to actively dismiss the past in favor of the future was a constant topic, as the following statement by a consultant highlights:

"I know many projects across Burkina, and here in Bagré they really have everything. And I talk to a lot of people here, and I can tell you that they don't want to change. They keep calling upon the authorities to do something for them, but they don't do their part. They remain in the old spirit, subsistence and each for himself, instead of organizing in collectives and understanding themselves as entrepreneurs. We need a shift here, otherwise we will stay behind. Bagré has it all, it's the best conditions and a lot of favorable support. But it has to come from them; the past must be left behind." (Field note, 18 August 2017)

The World Bank's call upon the government of Burkina Faso to actively commit to the future was translated into a call upon Bagré's farmers. As exemplified in the above quote, the zone authorities would often frame their work as providing the conditions for the possibility of the future to happen. What hindered the full realization of the future potential was the hesitation of the farmers to break with the past to fully embrace the project's vision. The farmers in turn addressed both the problematic ruptures between the past and the present project and the necessity to break with the past in order to realize the promises of the growth pole project.

In a round of talks between farmers and agents of the regional administration, together with zone managers and donor representatives, on the possibility of additional donorfunded programs at the level of the Ministry of Agriculture, a conversation arose on the problems the farmers were facing. Whereas the managing side pushed the conversation towards their plans for a digital tool to ensure information flows, the farmers steered the conversation towards the region's set- tlement history. Indeed, it was a common narrative among Bagré's farmers:

"When I came here, I received 1 ha [irrigable rice field] and some higher land [terres hautes] around the village [champs de case] for planting maize and some vegetables. The autochthones didn't cultivate that land before, I think. Or they were sent away; I don't know. But the MOB at the time took it and gave it to me. When Bagrépôle came and started the new constructions [under the World Bank-financed project] the people they displaced received money for their losses and were also guaranteed a plot on the new site. At this point, the autochthones rose up. They complained because they had never received any compensation. They came and claimed back their terres hautes. So today, I am left with the rice parcel and no garden to cultivate for myself. And what will I give to my sons? I cannot fight with the autochthones; it's their land." (Interview, 9 October 2017)

Back in the meeting room packed with farmers and representatives of different institutions the same point was made - today's major problems are rooted in the past. However, the farmer was hardly allowed to raise his concern, rather the strand of discussion was interrupted as soon as he had ended: "We should not look backwards. The history here is of no concern, we are here to talk about present needs and future possibilities" (FN, 12 September 2017). Nobody opposed the agent's interruption or insisted on keeping the conversation going. The remainder of the meeting centered around the farmers' wishes for cheaper seeds and fertilizer and easier access to farming equipment.

After the meeting, I joined the farmers who did not leave immediately but gathered outside of the building to exchange thoughts about the meeting and the state of their fields and news from the zone management. Puzzled about how the conflict situation was dealt with, I asked them what they thought about the incidence. After a moment of silence one of the farmers started: "It's complicated. There are more and more people and less and less land. There is not enough for everyone and this causes problems. But there is no return" (FN, 12 September 2017). The other farmers nodded in agreement. "So", I asked, "how can the problem be solved?" Another man answered: "Never mind. Ask Bagrépôle; they need to find a solution. We are not the ones deciding these things" (FN, 12 September 2017).

The agents' handling of the mentioning of land conflicts framing them as a past issue that would only hinder the arrival of the future and therefore must be dismissed - demonstrates that the complexity of and ambitions for the future require a cutting of the past, which is expected to happen on an institutional as well as an individual level. Interestingly, the farmers themselves, after meeting, joined the agent's position. The past seemed an issue too complicated to address, 
for which, if anyone, the authorities must find a solution. The turn of the conversation came as a surprise to me. And it was only the first of several incidences that revealed the ambiguous position of many farmers towards a past-present-future cut enforced by the project. While many farmers explained current problems and conflicts in terms of diverging temporal scales and goals between successive projects, e.g., shifting compensation schemes and project-transcending temporalities such as customary land tenure, they did not reject the prioritization of the future but used it to settle upcoming paradoxes as the above conversation shows. Return was not an option. Eventually the authorities would be able to find a solution, but otherwise they would leave it at that.

On another occasion, I addressed the problems that arose from the discontinuity of successive projects that operated in Bagré, in particular the conflicts regarding land tenure and questions of compensation in a conversation with a World Bank representative. Following my reasoning he nodded and resignedly shrugging his shoulders:

"We know that this happens and it causes problems. But you see, it wasn't a World Bank Project at the time and they didn't have rules for compensation. It's complicated. But things are moving forward, and this is what we have to focus on. Looking back, you start getting things wrong and accusing the project of taking land away. There is a whole bunch saying, we didn't get the land that we were promised. But that's automatically the former project, because no World Bank-converted land has been attributed yet. So, we say, leave the past aside and let's move on; otherwise the bank might say we are just shutting that thing down." (Interview, 20 October 2017)

As this passage demonstrates the successful realization of the promise of the future that the project entails relies on a fresh start. The project simply cannot - within its framework and with its resources - dissolve past configurations and conflicts. Therefore, it becomes imperative to leave the past behind.

The possibility of operating in an "emptied space" freed from the limiting structures of the past was regarded as a precondition for the project from its beginning as is reflected in the initial concept paper of the Bagré Growth Pole Project:

"The area directly concerned with potentially irrigable land below the dam, called the 'zone de concentration-ZC', covers about 50000 ha and has been declared 'zone d'utilite publique'. Within the ZC, customary land rights have been formally cleared and the land can thus be allocated by the State to any investors without further negotiations with/compensation to local populations (the area was previously an Onchocercose [sic] area and was very sparsely populated)." (World Bank, 2010a: 3)
The paragraph has been replaced in the final version by a more detailed examination of the complex land rights and titling issues, both legally and practically. However, the paragraph is instructive as it lays bare the dominant logic on which future-making in Bagré operates. It is regarded as an advantage that there is only little past (or pasts) to attend to, and that could stand in the way of the future. The flatter the past, the easier the future will cover it. Flattening the past, by dismissing it, thus becomes a crucial everyday strategy for future-making in Bagré.

During my fieldwork, I never observed any general open contestation to the growth pole as such. The vision of the region as a growth pole and the need to prioritize the future over the contested past seemed to be largely shared by managers and farmers alike. However, a more detailed look at the ideas for the concrete pathways that would lead to that future opened up spaces for slightly altered versions of the future growth pole. Whereas the need to bring in agro-investors that would farm larger plots and bring the financial means to significantly contribute to infrastructure development, such as the extension of the irrigation system, was emphatically pointed to by the managers, the farmers emphasized their own contribution to the current success of the project and insisted that the project should privilege them in the future and allocate more land to them and their growing families. Indeed, all actors shared the view of the land conversion and the related displacement and reordering of land tenure schemes as necessary pathways to the future. However, the question of who was to profit from this future was an open one. When the plots of the first extension were allocated in 2009, the farmers protested against the initial plan to give the land to agro-investors. Their intervention led the zone managers to allocate the land to the growing farmer families (Kaboré and Sédogo, 2014; Bazin, 2017). Irrigated, marketoriented agriculture might be the future, but it was the farmers that claimed their part of that particular vision, which the authorities had assigned to commercial investors. Still, the imperative to focus on the future at the expense of the past "works" and shapes the course of conversations and potentially actions, as two final quotes reveal:

"We envision a mix of farmers and agro-investors. But for the irrigation scheme to work, we need rules regarding the use of the land, the timing and also the organization. We put everything that is needed at the farmer's disposal, but if they don't follow the rules, then we have to enforce them and give the land to others. You know, we receive a lot of demands and no one has to cultivate rice. If they don't want to bring this forward, they can leave and settle somewhere else." (Interview with Bagrépôle manager, 24 July 2018)

"It will also be good for us when there are bigger farms around. There will then be roads and electricity and also employment opportunities for 
the youth." (Conversation with a farmer, field note, 30 July 2018)

While the first quote shows that the future the growth pole exhibits is framed as depending on the active choice of the farmers, the second reveals that the farmers - despite their critique in not gaining enough in terms of land and institutional support - still recognize the possibilities of the envisioned arrival of larger investors. Whereas on the management side the project leaves no space for negotiating the future it represents and the means to realize it - "If they don't want to bring this forward, they can leave and settle somewhere else" - the farmers attempt to carefully open up slightly altered versions of it without rejecting its overall orientation. The last quote by the farmer is also a reference to the infrastructural dimension of future-making in Bagré. In the second part of this analysis I will therefore look more deeply into the materializations of future possibilities as they occur in Bagré.

\subsection{Infrastructuring the future, channeling possibilities}

Infrastructure is central to the Bagré Growth Pole Project, and it is by far its most expensive component (World Bank, 2011). Infrastructure construction has also been crucial to prior projects in Bagré. In fact, the construction of the dam and the irrigation scheme can be understood as anchors that hold successive projects together and assure a minimum of continuity between them. Infrastructuring, as has been noted, entails "promises about the future" (Appel et al., 2018: 27), but it is also paradoxical (Howe et al., 2015) in that it "simultaneously index[es] the achievements and limits, expectations and failures, of modernity" (Appel et al., 2018: 27).

Satellite images of Bagré, in particular during the dry seasons, spectacularly depict the promise of infrastructure: green fields in the middle of barren landscapes, "vibrant agricultural activities at times when there was nothing but waiting for the rain before" (FN, 4 October 2017) as an agricultural agent put it. The massive landscape transformation has forced people to leave their lands and enabled others to settle, and it has brought new crops, rice most strikingly, to Bagré. But it has also significantly changed the affordances of that place. The fields that were created for the cultivation of rice can hardly be used for other crops as a farmer explained to me:

"When I open the water intake, the field is really flooded. Rice needs this, but other crops would just die. Also, Bagré is a rice region; everything here is adapted to it. We don't have the facilities to do something else." (Interview, 21 June 2018)

A particular infrastructure may enable a particular land use while disabling another. Infrastructures re-form the world and put new figurations of human-environment relations in place (Appel et al., 2018: 26). In Bagré however, they also bind a significant share of resources and will continue to do so. Infrastructures such as the dam, the canal network or the office buildings will require costly maintenance long after the Bagré Growth Pole Project ends if the investments are to be secured and maintained. Hence, once investments are made and infrastructures are installed, their form and function are unlikely to be completely reversed. Large-scale infrastructures such as Bagré's irrigation system endure and therefore shape how the future can be built; they literally shape the ground and lay the seeds for the future yet to come. In recent years, questions of path dependency have been addressed by the project through emphasizing the need for a diversified agriculture rather than banking on rice only. Still, the possibilities for land use are massively preconfigured by infrastructural means that for example privilege irrigated agriculture over livestock herding. ${ }^{3}$

Futures are not only built on infrastructures but also built into infrastructures. Right in the beginning of my fieldwork, I was invited to take one of the empty offices at the Maison de l'Entreprise in Bagré during my stays there. After my first day there, I wrote:

"The satellite office of the MEBF in Bagre is an impressive two-story building situated prominently along the unpaved main road that connects the artery road $(20 \mathrm{~km})$ Ouagadougou-Tenkodogo and southwards to Ghana, Togo and Benin with Bagré village and the irrigated rice plains of the Volta valley, downstream the Bagré dam.

The building seems quite new, I think it was built in 2012, the colors still shine and the yard is yet to be finished. It is a huge construction compared to the simple rectangular profiles of the single level surrounding buildings. Along the hallways it disposes of at least a dozen air-conditioned offices and a similar number of meeting and training rooms, kitchen space, sanitary installations and storage spaces. To my surprise, they were only a team of five people working here. Asking what all the space was planned for, I was told that the enterprises that would be founded and installed in Bagré would need office space and that the emergent business opportunities would attract consultants and associations." (FN, 19 June 2017)

When I returned to Bagré 1 year later, the offices were still empty. But besides the construction works going on in the yard, it became clear that some maintenance work had to be carried out inside as well. The rainy season had damaged the roof, and water had entered some of the rooms, including

\footnotetext{
${ }^{3}$ The herders mainly belonged to the ethnic group of the Fulbe. Since my fieldwork mainly focused on the rice sector, I did not follow the question of occasional conflicts between farmers and herders (see Korbéogo, 2020: 83-84).
} 
the archive where many reports and project proposals were stored.

Interestingly, around the same time, I attended a meeting of the to-be-established rice processor cooperative. The meeting was structured around a 5-year plan that was meant to define clear steps and assign responsibilities to the members-to-be. One of the processors raised the problem that "a cooperative, in order to work properly, would need a space where its members could have regular meetings, store documents, etc." (FN, 18 August 2017). Taking up his point we spent an hour to discuss potential locations, costs and resources, and income generated from renting the place out. Paying attention to infrastructuring reveals the specific futures that are anticipated and strived for. Rather than simply fulfilling present needs, infrastructure attends to visions of the future. They open discursive and material "as-if" spaces (Appel, 2017), but they seldom efficiently function as drivers. Offices for potential investors did not lead investors to come, and yet, they made Bagré ready for investors. While waiting for their arrival, the irrigation system as well as the building of the Maison de l'Entreprise in Bagré enduringly binds resources and literally channels future possibilities. Not only did the infrastructure component of the Bagré Growth Pole Project constitute the costliest project component, it also became the main argument for further interventions as was explained to me during an interview with a World Bank representative:

\begin{abstract}
"The World Bank funds the expansion of the irrigation system, as well as electricity and roads in the zone. Now, the construction of the channel system has become much more expensive than the initial calculations suggested. Currently, there isn't enough money for the road and the electricity, but additional financing to finish the project is in preparation. We have to get this done for the whole project to work." (Interview, 20 October 2017)
\end{abstract}

Because considerable investments had been made already, their potential had to be fully exhausted. Likewise, the office building hosting the Maison de l'Entreprise had to receive renovation and invest a considerable part of its budget into maintenance to secure and justify the past investments. "Maintenance work will soon start. We have to do this. Otherwise the place cannot attract potential investors and tenants" (FN, 3 June 2018).

Following on from this double-sided reference to infrastructure as both a means and an ends of future-making, the cooperative's concerns for an office building appear in a different light altogether. Whereas the functional need could have been fulfilled by renting rooms in the Maison de l'Entreprise, a new infrastructure promised further investments and possibilities in the future.

\section{Concluding remarks}

Attending to the logic and practices of development, planning and infrastructure, two modes of future-making in Bagré came to the fore. Within the Bagré Growth Pole Project practices were constantly oriented to a future, which had a priori been defined; and it did so by dismissing the past. The aim of the analysis is not primarily to criticize the future vision of the growth pole projects as such. Rather I point to the consequences of the prevailing prioritization of the future, that is the silencing of potential contestations and conflicts that could potentially lead to a renegotiation of the overall future vision. Although farmers and project managers alike (though to a different extent) recall experiences with former projects to explain current struggles as conditions and possibilities for future actions, they put considerable work into flattening the past to get it out of the way of the future. This "cutting" prevents people from using their past experiences as a resource in meaningful ways. Throughout the encounters I observed, attempts to bring in the past as an explanation for current problems or as an example for how things could be organized differently - as in previous projects - were consequently silenced with the hint that the past could not contribute to the future but was rather standing in its way. Yet, the occasional appearance of the past, e.g., in the explanation of lingering land conflicts, renders the efforts it takes to flatten and dismiss the past in the everyday life of Bagré visible. The constant reorientation of people's practices towards the future prevents reflections within the project on the results of past constellations that could be examined, analyzed and included to overcome the gap between envisioned future-making and reality as lived (Stein and Kalina, 2019: 83).

Infrastructure in turn extends ideas about the future through space and across time. Infrastructure plays a significant role in securing the future as it is envisioned by farmers and project managers. Through infrastructure the future takes shape and becomes tangible - it materializes. At the same time, it limits the future by channeling attention and concentrating resources. Infrastructure in this regard appears to be both a means and an ends of a politics of the future. In the course of infrastructure construction, the future is concretized bit by bit. Existing infrastructure projects are likely to receive further attention and funding, and often different infrastructures are built successively as they rely on one another to deliver a specific promised future.

A fine-grained analysis based on detailed empirical observations such as the one presented in this paper fosters an understanding of how a specific future is (un)made in practice, but it also provides a lens which may inform discussions about alternative and eventually more just futures more generally. It thereby contributes to the shared concern in much of current writings in anthropology and human geography on the future, namely to claim an active role in shaping the future in and of the fields of research. Bring- 
ing up sketches of slightly altered versions of the future that emerged from the concerns of my interlocutors, rather than openly criticizing the injustices of the project, enabled a continuous dialogue with different actor groups. Hence, attending to the future might lead to a more "generative critique" (Verran, 2001), thereby carefully and "gradually ... pushing forward the boundaries of political practice[s]" (Thrift, 2002) we study. It is therefore a crucial task for further research on the future to come up with research formats for the future, that is to help establish spaces where different future visions can be raised, debated and upheld rather than being closed down or prioritized all too easily.

Data availability. This paper is based on in-depth ethnographic fieldwork. The material includes interviews and personal field notes, which are not made publicly available in order to protect the privacy of the informants.

Competing interests. The author declares that they have no conflict of interest.

Acknowledgements. The author wishes to thank her supporters during fieldwork in Ouagadougou and Bagré, most notably Alban Traoré and his colleagues from the MEBF in Bagré as well as her research assistants Inoussa Ramde, Martin Wêndngûudi Compaoré and Souleymane Yougbaré, for practical support and patient translation work. I also thank Jean-Paul Yoda and Mamadou Kabré for their continuous reflections and ongoing friendship. At IRI THESys the fieldwork was supported by Olof Krüger, Jeannette Latino, Axel Klie and Patrick Hostert.

This paper has benefitted from extensive discussions with Jonas $\varnothing$. Nielsen and the research group on Integrative Geography at IRI THESys as well as with Jörg Niewöhner, Patrick Bieler, Milena Bister and Ruzana Liburkina from the Laboratory: Anthropology of Environment | Human Relations at the Institute for European Ethnology, Humboldt-Universität zu Berlin. Finally, I would like to thank the two anonymous reviewers and the editors of Geographica Helvetica for their feedback and valuable comments.

Financial support. The fieldwork has been supported by funds from the IRI THESys (Integrative Research Institute on Transformations of Human-Environment Systems), Humboldt-Universität zu Berlin, as part of the German Excellence Initiative.

Review statement. This paper was edited by Christiane Stephan and reviewed by two anonymous referees.

\section{References}

Abram, S. and Weszkalnys, G.: Elusive Promises: Planning in the Contemporary World, Berghahn Books, Oxford, New York, 2013.
Adam, B.: Of Timescapes, Futurescapes and Timeprints. Talk at Lüneburg University, 17 June 2008, available at: http://citeseerx.ist.psu.edu/viewdoc/download;jsessionid= 84E0A1E142BC32878B9CF566BA1E4CAC?doi=10.1.1.594. 1289\&rep=rep1\&type $=$ pdf (last access: 4 March 2021), 2008.

Adam, B. and Groves, C.: Future Matters. Action, Knowledge, Ethics, Brill, Leiden, Boston, 2007.

Anderson, B.: Preemption, precaution, preparedness: Anticipatory action and future geographies, Prog. Hum. Geog., 34, 777-798, 2010.

Anderson, B. and Fenton, J.: Editorial Introduction: Spaces of Hope, Space Cult., 11, 76-80, 2008.

Appadurai, A.: The Capacity to Aspire: Culture and the Terms of Recognition, in: Culture and Public Action, edited by: Rao, V. and Walton, M., Stanford University Press, Stanford, 59-84, 2004.

Appadurai, A.: The Future as Cultural Fact. Essays on the Global Condition, Verso, London, New York, 2013.

Appel, H.: Toward an Ethnography of the National Economy, Cult. Anthropol., 32, 294-322, 2017.

Appel, H., Anand, N., and Gupta, A.: Introduction: Temporality, Politics, and the Promise of Infrastructure, in: The Promise of Infrastructure, edited by: Anand, N., Gupta, A., and Appel, H., Duke University Press, Durham, London, 1-38, 2018.

Ballestero, A.: A Future History of Water, Durham, London, Duke University Press, 2019.

Barnes, J.: The future of the Nile: climate change, land use, infrastructure management, and treaty negotiations in a transboundary river basin, WIRES Clim. Change, 8, 1-18, 2017.

Bassole, H. F.: Bagrépôle : Un "rêve toujours réalisable" malgré sa complexité, reconnaît le directeur général, Joseph Martin Kaboré, lefaso.net, 10 December 2019, available at: https: //lefaso.net/spip.php?article93703 (last access: 4 March 2021), 2019.

Bazin, F.: Analyse des systèmes de production du périmètre irrigué de Bagré (Burkina Faso), available at: https://pubs.iied.org/fr/ G04200 (last access 4 March 2021), 2017.

Beckert, J.: Imagined Futures: Fictional Expectations in the Economy, Theor. Soc., 42, 219-240, 2013.

Beckert, J.: Imagined Futures. Fictional Expectations and Capitalist Dynamics, Harvard University Press, Cambridge, 2016.

Bogner, A., Littig, B., and Menz, W.: Interviewing Experts, Springer, Heidelberg, Dordrecht, New York, 2009.

Bonnecase, V.: Le goût du riz. Une valeur sensorielle et politique au Burkina Faso, Genèses, 2016/3(104), 7-29, 2016.

Braun, B.: Writing geographies of hope, Antipode, 37, 834-841, 2005.

Bryant, R. and Knight, D. M.: The Anthropology of the Future, Cambridge University Press, Cambridge, 2019.

Burkina Faso: Programme national du secteur rural (PNSR) 2011-2015, available at: http://www.inter-reseaux.org/IMG/pdf/ PNSR_version_19_dec_2011.pdf (last access: 4 March 2021), 2011.

Carse, A. and Kneas, D.: Unbuilt and Unfinished. The Temporalities of Infrastructure, Environment and Society, 10, 9-28, 2019.

Chome, N., Gonçalves, E., Scoones, I., and Sulle, E.: "Demonstration fields", anticipation, and contestation: agrarian change and the political economy of development corri- 
dors in Eastern Africa, J. East. Afr. Stud., 119, 291-309, https://doi.org/10.1080/17531055.2020.1743067, 2020.

Coulibaly, N.: Burkina Faso: mise en service du barrage hydroélectrique de Samendéni, in: Jeune Afrique, 1 December 2019, available at: https://www.jeuneafrique.com/863168/economie/burkina-fasomise-en-service-du-barrage-hydroelectrique-de,-samendeni/ (last access 4 March 2021), 2019.

Cross, J.: Dream Zones. Anticipating Capitalism and Development in India, Pluto Press, London, 2014.

Dannenberg, P., Revilla Diez, J., and Schiller, D.: Spaces for integration or a divide? New-generation growth corridors and their integration in global value chains in the Global South, Z. Wirtsch., 62, 135-151, 2018.

De Zeeuw, F.: Borrowing of Land, Security of Tenure and Sustainable Land Use in Burkina Faso, Dev. Change, 28, 583-595, 1997.

Dialla, B. É.: La sécurité foncière sur les périmètres irrigués du Burkina Faso: le cas de la vallée du Sourou, Africa Development/Afrique et Développement, 27, 62-83, 2002.

Dunn, K.: Interviewing, in: Qualitative Research Methods in $\mathrm{Hu}-$ man Geography, edited by: Hay, I., Oxford, Oxford University Press, 99-137, 2010.

Elliott, H.: Planning, property and plots at the gateway to Kenya's "new frontier", J. East. Afr. Stud., 10, 511-529, 2016.

Enns, C.: Mobilizing Research on Africa's Development Corridors, Geoforum, 88, 105-108, 2018.

Enns, C.: Infrastructure projects and rural politics in northern Kenya: the use of divergent expertise to negotiate the terms of land deals for transport infrastructure, J. Peasant Stud., 46, 358376, 2019.

FAO: Burkina Faso. Country Fact Sheet on Food and Agriculture Policy Trends, available at: http://www.fao.org/3/i3760e/i3760e. pdf (last access: 4 March 2021), 2014.

Faure, A.: Le pays bissa avant le barrage de Bagré, Sepia, Paris, Ouagadougou, 1996.

Ferguson, J.: Expectations of Modernity: Myths and Meanings of Urban Life on the Zambian Copperbelt, University of California Press, Berkeley, Los Angeles, 1999.

Geenen, S.: Underground Dreams. Uncertainty, Risk and Anticipation in the Gold Production Network, Geoforum, 91, 30-38, 2018.

Goldstone, B. and Obarrio, J.: African Futures. Essays on Crisis, Emergence, and Possibility, University of Chicago Press, Chicago, London, 2016a.

Goldstone B. and Obarrio J.: Introduction: Untimely Africa? in: African Futures, edited by: Goldstone B. and Obarrio J., University of Chicago Press, Chicago, London, 1-19, $2016 \mathrm{~b}$.

Greiner, C.: Land-Use Change, Territorial Restructuring, and Economies of Anticipation in Dryland Kenya, J. East. Afr. Stud, 10, 530-547, 2016.

GRiSP: Rice Almanac, International Rice Research Institute (IRRI), Los Baños, Philippines, 2013.

Gupta, A.: Authorship, research assistants and the ethnographic field, Ethnography, 15, 394-400, 2014.

Harsch, E.: Burkina Faso. A History of Power, Protest, and Revolution, Zed Books, London, 2017.

Hauer, J. and Nielsen, J. Ø.: Making land-use change and markets: the global-local entanglement of producing rice in Bagré, Burkina Faso, Geogr. Ann. B, 102, 84-100, https://doi.org/10.1080/04353684.2020.1723121, 2020.

Hauer, J., Nielsen, J. Ø., and Niewöhner, J.: Landscapes of Hoping - Urban Expansion and Emerging Futures in Ouagadougou, Burkina Faso, Anthropol. Theor., 18, 59-80, 2018.

Hilgers, M.: Politiques urbaines, contestation et décentralisation: Lotissement et représentations sociales au Burkina Faso, Autrepart, 47, 209-226, 2008.

Howe, C., Lockrem, J., Appel, H., Hackett, E., Boyer, D., Hall, R., Schneider-Mayerson, M., Pope, A., Gupta, A., Rodwell, E., Ballestero, A., Durbin, T., el-Dahdah, F., Long, E., and Mody, C.: Paradoxical Infrastructures: Ruins, Retrofit, and Risk, Sci. Technol. Hum. Val., 41, 547-565, 2015.

Hull, M. S.: Government of Paper: The Materiality of Bureaucracy in Urban Pakistan, University of California Press, Berkeley, 2012.

Jansen, S.: Hope For/Against the State: Gridding in a Besieged Sarajevo Suburb, Ethnos, 79, 238-260, 2014.

Jasanoff, S. and Kim, S. H.: Containing the Atom: Sociotechnical Imaginaries and Nuclear Power in the United States and South Korea, Minerva, 47, 119-146, 2009.

Jasanoff, S. and Kim, S. H.: Dreamscapes of Modernity: Sociotechnical Imaginaries and the Fabrication of Power, University of Chicago Press, Chicago, 2015.

Kaboré, E. and Sédogo, S. A.: Economie politique autour des grands barrages: Le cas du barrage de Bagré, Burkina Faso, available at: https://pubs.iied.org/fr/14642IIED (last access: 4 March 2021), 2014.

Korbéogo, G.: Framing the Fluidity of Water Management Conflicts in the Bagré Irrigation Scheme, Burkina Faso, Water Altern., 13, 70-92, 2020.

Kornienko, K.: Waiting, Hope, Democracy, and Space: How Expectations and Socio-economic Rights Shape Two South African Urban Informal Communities, J. Asian Afr. Stud., 52, 34-49, 2014

Larkin, B.: The Politics and Poetics of Infrastructure, Annu. Rev. Anthropol., 42, 327-343, 2013.

Larkin, B.: Promising Forms: The Political Aesthetics of Infrastructure, in: The Promise of Infrastructure, edited by: Anand, N., Gupta, A., and Appel, H., Duke University Press, Durham, London, 175-202, 2018.

Lewis, D.: International development and the "perpetual present": Anthropological approaches to the re-historicization of policy, Eur. J. Dev. Res., 21, 32-46, 2009.

Longhurst, R.: Semi-structured Interviews and Focus Groups, in: Key Methods in Geography, edited by: Clifford, N. J. and Valentine, G., Sage, Los Angeles, London, 117-132, 2003.

MAAH: Strategie Nationale de Developpement de la Riziculture, available at: https://riceforafrica.net/downloads/ Countries/BurkinaFaso/Burkina_Faso_SNDR_Fr.pdf (last access: 4 March 2021), 2011.

MacKendrick, N.: Foodscape, Contexts, 13, 16-18, 2014.

Marcus, G.: Afterword. Ethnography between the Virtue of Patience and the Anxiety of Belatedness Once Coevalness Is Embraced, in: Time and the Field, edited by: Dalsgaard, S. and Nielsen, M., Berghahn, New York, Oxford, 143-155, 2016.

Mathieu, P., Zongo, M., and Paré, L.: Monetary Land Transactions in Western Burkina Faso: Commoditization, Papers and Ambiguities, in: Securing Land Rights in Africa, edited by: Benjamin- 
sen, T. A. and Lund, C., Frank Cass, London, Portland, 109-128, 2003.

Meehan, K. M.: Tool-power: Water infrastructure as wellsprings of state power, Geoforum 57, 215-224, 2014.

Middleton, T. and Cons, J.: Coming to Terms: Reinserting Research Assistants into Ethnography's Past and Present, Ethnography, 15, 279-290, 2014.

Mitman, G., Armiero, M., and Emmett, R. (eds): Future remains: a cabinet of curiosities for the anthropocene, University of Chicago Press, Chicago, London, 2017.

Mosley, J. and Watson, E. E.: Frontier transformations: development visions, spaces and processes in Northern Kenya and Southern Ethiopia, J. East. Afr. Stud., 10, 452-475, 2016.

Müller-Mahn, D.: Envisioning African Futures: Development corridors as dreamscapes of modernity, Geoforum, 115, 156-159, https://doi.org/10.1016/j.geoforum.2019.05.027, 2019.

Nielsen, M.: Futures Within: Reversible Time and House-Building in Maputo, Mozambique, Anthropol. Theor., 11, 397-423, 2011.

Nielsen, M.: A wedge of time: futures in the present and presents without futures in Maputo, Mozambique, J. Roy. Anthropol. Inst., 20, 166-182, 2014.

Niewöhner, J.: Infrastructures of Society (Anthropology of), in: International Encyclopedia of the Social \& Behavioral Sciences (Second Edition), edited by: Wright, J. D., Elsevier, Oxford, 119-125, 2015.

Ouedraogo, O. and Sedogo, S. A.: Les enjeux pour les petits producteurs dans l'irrigation à grande échelle - le cas du barrage de Bagré au Burkina Faso, available at: https://pubs.iied.org/fr/ G04220 (last access: 4 March 2021), 2014.

Ouma, S., Hughes, A., Murphy, J. T., and Opondo, M.: Envisioning African futures: Perspectives from economic geography, Geoforum, 115, 146-147, https://doi.org/10.1016/j.geoforum.2019.05.030, 2019.

Picard, F., Coulibaly, M., and Smaller, C.: The Rise of Agricultural Growth Poles in Africa, International Institute for Sustainable Development, available at: https://www.iisd.org/system/files/ publications/rise-agricultural-growth-poles-in-africa.pdf (last access: 4 March 2021), 2017.

Prat, A.: Ouagadougou, Capitale Sahélienne: Croissance Urbaine et Enjeu Foncier, Mappemonde, 41, 18-24, 1996.

Rabinow, P., Marcus, G. E., Faubion, J. D., and Rees, T.: Designs for an Anthropology of the Contemporary, Duke University Press, Durham, London, 2008.

Ringel, F.: On expectations in the aftermath of the "refugee crisis": Ethnographic prospects from a post-industrial German city, Anthropology Today, 34, 26-28, 2018.

Schatzki, T. R.: Where the Action Is (On Large Social Phenomena Such as Sociotechnical Regimes), Sustainable Practices Research Group Working Paper, 1, available at: http://www.sprg.ac. uk/uploads/schatzki-wp1.pdf (last access 23 April 2021), 2011.

Schindler, S., Fadaee, S. and Brockington, D.: Contemporary Megaprojects, Environment and Society, 10, 1-8, 2019.

Sennett, R.: Building and dwelling: ethics for the city, Farrar, Straus and Giroux, New York, 2018.

Speakman, J. and Koivisto, M.: Growth Poles: Raising Competitiveness and Deepening Regional Integration, in: The Africa Competitivenes Report 2013, edited by: Bank, T. W., World Economic Forum, Geneva, 93-106, 2013.
Star, S. L.: The Ethnography of Infrastructure, Am. Behav. Sci., 43 , 377-391, 1999.

Stein, S. and Kalina, M.: Becoming an Agricultural Growth Corridor: African Megaprojects at a Situated Scale, Environment and Society, 10, 83-100, 2019.

Stoler, A. L.: Imperial Debris: On Ruins and Ruination, Duke University Press, Durham, London, 2013.

Thrift, N.: The future of geography, Geoforum 33, 291-298, 2002.

Trovalla, E. and Trovalla, U.: Infrastructure as a divination tool: Whispers from the grids in a Nigerian city, City, 19, 332-343, 2015.

Venot, J. P., Dare, W. S., Kabore, E., Gerard, F., Tapsoba, A., Idani, D., and Carboni, S.: Ideologies. Development Models and Irrigated Land Tenure: The Bagré Irrigation Project in Burkina Faso, World Bank Conference on Land and Poverty, The World Bank, Washington DC, 2017.

Verran, H.: Science and an African Logic, University of Chicago Press, Chicago, London, 2001.

von Schnitzler, A.: Democracy's Infrastructure. Techno-Politics and Protest after Apartheid, Princeton University Press, Princeton, Oxford, 2016.

Wang, J. and Li, P. F.: Growth Poles and Growth Centers, in: International Encyclopedia of Geography, edited by: Richardson, D., Castree, N., Goodchild, M. F., Kobayashi, A., Liu, W., and Marston, R. A., John Wiley and Sons, New York, 1-7, 2017.

Wiegink, N.: Imagining Booms and Busts: Conflicting Temporalities and the Extraction-"Development" nexus in Mozambique, The Extractive Industries and Society, 5, 245-252, 2018.

Wopereis, M. C., Johnson, D. E., Ahmadi, N., Tollens, E., and Jalloh, A.: Realizing Africa's Rice Promise, CABI, Wallingford, Boston, 2013.

World Bank: Burkina Faso - Bagre Growth Pole Project (English), available at: https://documents.worldbank.org/en/publication/ documents-reports/documentdetail/774001468019806803/

burkina-faso-bagre-growth-pole-project (last access 23 April 2021), 2010a.

World Bank: Burkina Faso: Advance Agreement for Preparation of Proposed Bagré Growth Pole Project, available at: http: //documents.worldbank.org/curated/en/592771468215113272/ Agreement-for-Preparation-Advance-Q740-BF-Conformed (last access: 4 March 2021), 2010b.

World Bank: Project Appraisal Document on a Proposed Grant in the Amount of SDR 71 Million (US\$ 115 Million Equivalent) to Burkina Faso for a Bagré Growth Pole Project, available at: http: //documents.worldbank.org/curated/en/581451468020361287/ Burkina-Faso-Bagre-Growth-Pole-Project (last access: 4 March 2021), 2011.

Yaméogo, L.: Territorialisation hydraulique et développement local autour du lac de Bagré (Burkina Faso), Thèse de doctorat, Université de Padova, Italy, 2006.

Yaméogo, L.: Le pôle de croissance de Bagré dans la nouvelle projectualité du développment au Burkina Faso, Rivista Geografica Italiana, 122, 305-322, 2015.

Yarrow, T.: Remains of the Future: Rethinking the Space and Time of Ruination through the Volta Resettlement Project, Ghana, Cult, Anthropol, 32, 566-591, 2017. 